Cite as: Montague, A. C., \& Eiroa-Orosa, F. J. (2018). In it together: Exploring how belonging to a youth activist group enhances well-being. Journal of Community Psychology, 46(1), 23-43. http://doi.org/10.1002/jcop.21914

\title{
In it together: Exploring how belonging to a youth activist group enhances well-being
}

Anne C. Montague ${ }^{1}$, Francisco Jose Eiroa Orosa ${ }^{2,3}$

1. The Human Rights Action Centre, Amnesty International UK Section

2. Section of Personality, Evaluation and Psychological Treatment; Department of Clinical Psychology and Psychobiology; University of Barcelona

3. Yale Program for Recovery and Community Health; Yale School of Medicine, Department of Psychiatry 
Cite as: Montague, A. C., \& Eiroa-Orosa, F. J. (2018). In it together: Exploring how belonging to a youth activist group enhances well-being. Journal of Community Psychology, 46(1), 23-43. http://doi.org/10.1002/jcop.21914

\title{
In it together: Exploring how belonging to a youth activist group enhances well-being
}

\begin{abstract}
Despite some evidence that being an activist, particularly during adolescence, can have a positive impact on well-being, activism has been relatively neglected in both psychology and youth civic engagement research. This study aimed to address this gap by exploring how being an activist as a teenager positively impacts personal development and wellbeing. Seven focus groups were held with adolescent human rights activists. Inductive thematic analysis was used to identify four dominant themes: A place to go, Power in Numbers, Skilling-Up and In it together. These themes are discussed in relation to existing literature and, since findings from this study suggests that there are a number of positive psychological benefits to being a youth activist, implications for psychology and youth civic engagement are considered.
\end{abstract}

Keywords: youth activism; youth civic engagement; personal development, well-being 
Cite as: Montague, A. C., \& Eiroa-Orosa, F. J. (2018). In it together: Exploring how belonging to a youth activist group enhances well-being. Journal of Community Psychology, 46(1), 23-43. http://doi.org/10.1002/jcop.21914

\section{Introduction}

According to the literature, being an activist can have a number of psychological benefits such as developing a sense of mastery and displaying higher levels of subjective vitality (e.g. Gilster, 2012; Klar \& Kasser, 2009). Since adolescence is such an important developmental phase of life (e.g. Marcia, 1966), being an activist as a teenager could have particular benefits for well-being and personal development such as developing a sense of belonging and socio-political awareness (e.g. Morsillo and Prilleltensky, 2007). Activism would therefore seem a relevant research area for psychology and related fields such as 'youth civic engagement'. However, there are still gaps in the research on the positive impact of activism on adolescent well-being within the fields of psychology and youth civic engagement in that both have tended to focus primarily on 'service-giving' activities such as volunteering and have not necessarily recognised activism as a distinct activity worthy of separate study in its own right (Gilster, 2012; Watts \& Flanagan, 2007). This study hopes to address these gaps by exploring what impact being involved in activism has on the well-being and personal development of youth activists.

A broad view of the term well-being is used for the purposes of this study. Whilst the focus has been firmly on the subjective psychological well-being and personal development of the participants, our conceptualization goes beyond the presence of positive affective states, such as positive emotions and life satisfaction, to include broader constructs as socio-political development (Watts, Williams, \& Jagers, 2003), meaning (Wong, 2012), collective accomplishment (Shamir, 1990), resilience (Zimmerman et al., 2013) and empowerment (Kieffer, 1984) as outlined in a number of community-oriented well-being models (Di Martino, Eiroa-Orosa, \& Arcidiacono, 2017). The authors take the view that this broader conceptualization takes into account the process of relational 
Cite as: Montague, A. C., \& Eiroa-Orosa, F. J. (2018). In it together: Exploring how belonging to a youth activist group enhances well-being. Journal of Community Psychology, 46(1), 23-43. http://doi.org/10.1002/jcop.21914

empowerment (Christens, 2012) that takes place through critical consciousness (Christens, Winn, \& Duke, 2016) in youth activism contexts.

This study used Klar and Kasser's (2009) definition of activism, that is "the behaviour of advocating some political cause (for instance, protecting the environment, human rights issues, opposing abortion, or preventing wars) via any of a large array of possible means, ranging, for example, from institutionalised acts such as starting a petition to unconventional acts such as civil disobedience" (p.3). This definition aligns with Gilster (2012) and the researchers' own belief that activism is a distinct activity that involves engaging critically in projects that try to change the community or societal status quo as opposed to service-giving activities such as community volunteering which tend to work within the current social system. However, others have conceptualised activism as falling under the general concept of volunteering (e.g. Wilson, 2000). The rest of this section is dedicated to an overview of relevant research on activism, as defined above, followed by the specific research question and rationale of the current study.

\section{Activism and well-being}

The numerous psychological benefits of volunteering, which for some in theory includes the concept of activism, has received a significant amount of attention from researchers (e.g. Meier \& Stutzer, 2008; Thoits \& Hewitt, 2001). However, as discussed above, some believe that activism is a different experience to volunteering and, whilst there is plenty of research on activism as a general topic (e.g. Mccarthy, 1981; Vestergren, Drury, \& Chiriac, 2016), some argue that activism and its relationship to psychological well-being has been largely neglected by psychology in general (Gilster, 2012).

A small number of studies can be found, however, that have attempted to investigate the psychological benefits of being involved in activism. In a quantitative study, Klar and Kasser (2009) showed that research participants who took part in a one- 
Cite as: Montague, A. C., \& Eiroa-Orosa, F. J. (2018). In it together: Exploring how belonging to a youth activist group enhances well-being. Journal of Community Psychology, 46(1), 23-43. http://doi.org/10.1002/jcop.21914

off activism activity (writing to the director of their college cafeteria to ask for more fair trade food to be provided) displayed greater levels of subjective vitality than those who took part in a non-activist activity (writing to the director to ask that the taste of the food be improved). Using data from a large community health study, Gilster (2012) differentiated between those involved in community activism and those who volunteered. Those who took part in community activism showed a greater sense of personal control, or mastery, leading Gilster (2012) to conclude that activism and volunteering are different experiences. A number of qualitative studies have explored the relationship between wellbeing and activism, with Downton and Wehr's (1998) study of peace activists highlighting the development of resilience, social connections and skills whilst Eigner's (2001) study of environmental activists also revealed social contact to be a benefit of activism alongside joy and efficacy. Harré, Tepavac and Bullen (2009) found feelings of efficacy and integrity as important to political activists.

\section{Youth activism and well-being}

Given that adolescence is an important developmental stage of life (N. Eisenberg \& Fabes, 1998; Hart \& Carlo, 2005; Marcia, 1966), it has been asked whether being an activist as a teenager could have particular psychological benefits (e.g. Ginwright, 2003; Kirshner, 2007). In theory, activism as a concept appears within youth civic engagement literature, a broad term encompassing various pro-social activities such as volunteering or fighting for social justice (Ekman \& Amnå, 2012; Sullivan, Edwards, Johnson, \& McGillicuddy, 2003). However, criticisms of the field have been raised namely that youth civic engagement tends to focus predominantly on volunteering and neglects activism as a distinct form of civic engagement (Yohalem \& Martin, 2007). Similarly, Watts and Flanagan (2007) argue that it has focussed too much on service-giving activities that maintain the status quo rather than those that are trying to change society whilst Sherrod 
Cite as: Montague, A. C., \& Eiroa-Orosa, F. J. (2018). In it together: Exploring how belonging to a youth activist group enhances well-being. Journal of Community Psychology, 46(1), 23-43. http://doi.org/10.1002/jcop.21914

(2006) identified three areas as the main focus of youth civic engagement as a field, namely civic education, school activities and community service projects noting that, 'these three mechanisms by no means would lead youth to adopt an activist orientation toward citizenship -to notice or be concerned with social justice' (p.292). These criticisms of the youth civic engagement field appear to echo observations in the nonyouth specific arena discussed above which also highlights an over emphasis on volunteering and the relative lack of research on activism as a distinct activity worthy of study in its own right (Gilster, 2012).

There are a small number of studies, however, that do make reference to youth activism as a distinct form of civic engagement with a variety of positive well-being outcomes, with Harré's (2007) literature review on community service and activism revealing that sense of belonging, living according to ones values, efficacy and stimulation are key benefits of both activism and community service. Kirshner (2009) found high levels of collective efficacy amongst youth activists whilst development of strategic thinking was the main outcome of activism according to Larson \& Hansen (2005). For Morsillo and Prilleltensky (2007) socio-political awareness, hopefulness and belonging were key outcomes. Both 'activists' and 'helpers' in Pancer, Pratt, Hunsberger, \& Alisat's (2007) study displayed higher levels of identity development and emotional adjustment than those who did nothing though this result was correlational not causal. Pearce and Larson (2006) found high levels of intrinsic motivation amongst activists, although they were studying the same youth project as Larson and Hansen (2005) which could limit generalisability. Watkins, Larson \& Sullivan (2007) found that activism helped to bridge barriers between young people of different ethnic backgrounds.

This study aims to explore how being part of a youth activist group enhances the psychological well-being and personal development of youth activists and was conducted 
Cite as: Montague, A. C., \& Eiroa-Orosa, F. J. (2018). In it together: Exploring how belonging to a youth activist group enhances well-being. Journal of Community Psychology, 46(1), 23-43. http://doi.org/10.1002/jcop.21914

with adolescent human rights activists in the UK. It hopes to make a small contribution to a relatively neglected area in the fields of both psychology and youth civic engagement, which have tended to favour research on service-giving activities, such as volunteering, and to build on existing research which recognises that activism is a distinct form of youth civic engagement that can have a number of positive psychological well-being outcomes (Montague \& Eiroa-Orosa, 2017). It takes a qualitative approach since this is appropriate for relatively under-researched areas and for exploring some of the developmental processes behind peoples experiences which cross-sectional studies such as Gilster (2012), Klar and Kasser (2009) and Pancer, Pratt, Hunsberger, \& Alisat's (2007) cannot achieve (Creswell, 2014). This study addresses Klar and Kasser's (2009) recommendation of investigating the impact of regular activism on issues of participants' own choice rather than the one-off act of activism the participants of their study were asked to take. Similarly, Pearce and Larson's (2006) perception that young activists need to be personally affected by the issues they work on in order to reap positive well-being outcomes could be challenged by this study given that these activists were working on human rights issues they were unlikely to be personally affected by.

\section{Method}

\section{Design}

This study used focus groups to explore the role that activism plays on the wellbeing of youth activists. A qualitative approach was taken given its suitability when there is need to delve into novel aspects of a topic (Creswell, 2014). The method followed was Braun and Clarke's (2006) 6-stage thematic analysis (TA) given its flexibility and was inductive in nature as the researchers wanted to take an exploratory approach. An advantage of this type of TA is its compatibility with a number of epistemological positions (Braun \& Clarke, 2006). This study took a social constructionist stance, 
Cite as: Montague, A. C., \& Eiroa-Orosa, F. J. (2018). In it together: Exploring how belonging to a youth activist group enhances well-being. Journal of Community Psychology, 46(1), 23-43. http://doi.org/10.1002/jcop.21914

acknowledging that research outcomes are co-created between researcher and participants and accepting that the researcher's belief systems will shape interpretation of the data. For example, it should be noted that the study was linked to the main researcher's professional life. They are a staff member of the organisation from which the participants were recruited, responsible for supporting youth activists affiliated to that organisation. This could potentially influence the interpretations of the data made by the main researcher (Creswell, 2014). Permission to approach youth groups was given by senior managers at Amnesty International.

\section{Participants}

32 members of the Amnesty International UK's (AIUK) youth group network were recruited. They came from AIUK youth groups based in seven different schools. These youth groups are set up in individual schools and colleges across the UK and provide students the opportunity to collectively campaign on human rights issues. Participants were between the ages of 14 and 18 and consisted of 12 boys and 20 girls. Each focus group comprised of 4-5 members of the same AIUK youth group and were students of the same school. They took place in a variety of locations in England with most taking place in southern England and one taking place in the north. Two out of the 32 focus group participants had previously met the main researcher in the context of other projects.

\section{Recruitment process}

Ethical approval was received from the University of East London Ethics Committee. An email outlining the aims of the research, number of students needed, timecommitment and levels of consent required was sent to adult leaders of approximately 500 youth groups to gauge initial interest. The researcher asked for 4-5 participants per focus group since good practice advises that focus groups with under-18s should be 
Cite as: Montague, A. C., \& Eiroa-Orosa, F. J. (2018). In it together: Exploring how belonging to a youth activist group enhances well-being. Journal of Community Psychology, 46(1), 23-43. http://doi.org/10.1002/jcop.21914

smaller than with adults (Shaw, Brady, \& Davey, 2011). 33 adult leaders replied expressing interest and stating they were confident that members of their youth group would be interested in taking part. A follow up email was then sent asking for a general overview of the demographics of the youth group members. At this stage prioritisation was given to the recruitment of participants of similar age since large age gaps are a key factor impacting focus group dynamics (Heary, 2002). Next, other practical issues were considered including being able to travel to a financially affordable geographical location and running a realistic number of focus groups given both the researcher's and participants' time constraints. As a result, the first seven groups who responded and met these criteria were selected.

Once the youth group was selected, the adult group leader was sent official information sheets and consent forms. It was left to the adult leaders' discretion to introduce the project, select suitable participants, distribute relevant consent forms and ensure participants knew where and when the focus group would be taking place. As most participants were under 18, consent from parents/guardians was sought and, as research took place on school premises, permission from relevant school authorities was gained. Consent forms and invitations were sent directly to the adult youth group leader ensuring that the researcher did not have access to personal details of minors.

\section{Data collection}

Focus groups were chosen as a suitable method of data collection for this study. There are undeniably several limitations to focus groups. These include the logistical challenges of getting numerous people in the same place at the same time, they are harder to transcribe since participants tend to talk over each other and they do not typically allow for much follow-up of individual contributions (Braun \& Clarke, 2006). However, focus groups were ultimately chosen as a suitable method for this study for their numerous 
Cite as: Montague, A. C., \& Eiroa-Orosa, F. J. (2018). In it together: Exploring how belonging to a youth activist group enhances well-being. Journal of Community Psychology, 46(1), 23-43. http://doi.org/10.1002/jcop.21914

advantages. Participants get to interact with each other which can potentially yield richer data (Heary, 2002), they are a good tool for exploring under-researched areas (Braun \& Clarke, 2006) and can be less intimidating than one-to-one interviews (Heary, 2002). However, most importantly, focus groups can be particularly beneficial when working with children as they can help to mitigate against power imbalances between adult and child which can be a feature of one-to-one interviews (Heary, 2002).

Seven focus groups were conducted lasting between 40-50 minutes, considered to be a good length for focus groups with under-18s (Heary, 2002; Shaw et al., 2011). They took place in classrooms known to participants and at a time that suited them to help ensure they were as relaxed as possible (Shaw et al., 2011). Adhering to individual school policies, three out of the seven focus groups required having another adult present. These adults focussed on other activities such as correcting student school work. Before the groups started participants were reminded of the purpose of the study, that they could withdraw and that it was confidential with the exception that the researcher would let authorities know if a participant disclosed abuse (Shaw et al., 2011).

A schedule of semi-structured questions (Table 1) was drafted to guide the conversation. Given the inductive, exploratory nature of this study the authors endeavoured to ensure that these questions were as broad as possible and limited influencing the participants' responses. A creative warm-up activity to relax participants, recommended for focus groups with children (Shaw et al., 2011), was carried out. This asked them to explore either visually or verbally what their AIUK youth group meant to them. Participants were given a verbal and written debrief afterwards including providing the details of Childline, a children's support group in the UK. Focus groups were recorded with consent by participants on both a dictaphone and smart phone. The researchers were conscious of the risk of influencing the data, for example by potentially asking leading 
Cite as: Montague, A. C., \& Eiroa-Orosa, F. J. (2018). In it together: Exploring how belonging to a youth activist group enhances well-being. Journal of Community Psychology, 46(1), 23-43. http://doi.org/10.1002/jcop.21914

questions or by being involved professionally in the subject matter. A reflexive memo was therefore written after each focus group to give the researchers a chance to reflect on how they may have influenced the data. Transcription was done by the first author. All names mentioned were changed to preserve anonymity.

Table 1. Focus group schedule

Welcomes. Introduce the purpose of the interview and thank them for taking part. Reiterate that the study is confidential, voluntary and that participants can withdraw. Remind them that it will be recorded. Explain that the focus groups/interviews will be informal in nature, that there are no right or wrong answers and it will last 45 minutes.

Warm up activity: Give participants pens and paper. Ask them to either draw or sum up in a few key words, what their Amnesty group means to them.

1. Can you tell me a little bit about how long you've been involved in your Amnesty group and why you first got involved?

2. What keeps you going to Amnesty group meetings week after week?

3. What does a really good Amnesty meeting look and feel like?

4. Can you describe one of your best experiences being part of your group?

5. How important is it to you to take action together with other people?

6. Tell me a little bit about how you work together as a group - with each other and with your teacher.

7. Thinking about how you were when you first started going to Amnesty meetings compared to how you are now, do you think that being involved in the group has changed you at all? If so, how? 
Cite as: Montague, A. C., \& Eiroa-Orosa, F. J. (2018). In it together: Exploring how belonging to a youth activist group enhances well-being. Journal of Community Psychology, 46(1), 23-43. http://doi.org/10.1002/jcop.21914

\section{Data analysis}

Formal analysis started once 7 focus groups had been completed. Braun and Clarke's (2006) 6-stage approach to TA was followed. The first stage involved deep familiarisation with the data by repeated readings of transcripts after which formal exploratory line-by-line coding began. The researcher was inclined at this stage to code anything deemed potentially relevant even if it did not make it to the final analysis. Codes were collated with relevant data in an Excel spreadsheet. The next stage involved focussed coding whereby exploratory codes were grouped together into potential themes. It was at this stage that it was endeavoured to move from the more descriptive interpretations of codes to more latent interpretations. A smaller number of core themes were identified by repeating this process several times. The next stage involved refinement of themes including devising suitable names that summed up a coherent central organising concept. This entire process was iterative involving continual 'testing' of potential themes by referring back to the original data. The final stage was writing up the findings, a phase in the analytical process itself with further refinements being made. Thematic saturation was considered to be achieved after these 7 focus groups and therefore data collection was completed at that point.

\section{Results}

Four main themes were identified, each with several sub-themes as summarised in Table 2 and each will be discussed using illustrative quotes. Each of the seven focus groups has been given a number from 1-7 and the number of the specific focus group being quoted is given in brackets, along with the relative frequency the theme appeared across the focus groups. Some smaller sub-themes appear ('Brushing it Off' and 'Safety in Numbers') as it was felt they had conceptual independence despite not appearing in great frequency across all focus groups. 
Cite as: Montague, A. C., \& Eiroa-Orosa, F. J. (2018). In it together: Exploring how belonging to a youth activist group enhances well-being. Journal of Community Psychology, 46(1), 23-43. http://doi.org/10.1002/jcop.21914

Table 2. Themes found in the qualitative analysis

\begin{tabular}{|c|c|c|c|c|c|}
\hline Theme & Sub-theme & $\#$ & $\begin{array}{l}\text { Focus } \\
\text { group }\end{array}$ & $\begin{array}{l}\text { How many } \\
\text { participants } \\
\text { per group } \\
\text { mentioned } \\
\text { the theme (at } \\
\text { least once) }\end{array}$ & $\begin{array}{l}\text { How many times } \\
\text { theme was } \\
\text { mentioned per } \\
\text { group }\end{array}$ \\
\hline 1. A place to & 1.1 Opening Eyes & 7 & 1 & $4 / 5$ & 7 \\
\hline go & [becoming aware & & 2 & $5 / 5$ & 11 \\
\hline [group as & of / passionate & & 3 & $4 / 4$ & 18 \\
\hline place to & about human & & 4 & $3 / 5$ & 4 \\
\hline express and & rights] & & 5 & $2 / 4$ & 6 \\
\hline develop & & & 6 & $4 / 4$ & 9 \\
\hline awareness of & & & 7 & $2 / 5$ & 2 \\
\hline and interest in & 1.2 Don't just sit & 6 & 1 & $5 / 5$ & 10 \\
\hline human rights & there, do & & 2 & $4 / 5$ & 15 \\
\hline \multirow[t]{12}{*}{ issues] } & something! & & 3 & $3 / 4$ & 9 \\
\hline & [developing an & & 4 & $5 / 5$ & 13 \\
\hline & activist & & 5 & $4 / 4$ & 12 \\
\hline & identity/doing & & 6 & $4 / 4$ & 18 \\
\hline & $\begin{array}{l}\text { something to } \\
\text { protect human } \\
\text { rights] }\end{array}$ & & 7 & $0 / 5$ & 0 \\
\hline & $1.3^{\text {'It's fun, }}$ & 6 & 1 & $1 / 5$ & 11 \\
\hline & frankly' & & 2 & $3 / 5$ & 6 \\
\hline & [enjoying yourself & & 3 & $3 / 4$ & 10 \\
\hline & whilst being an & & 4 & $4 / 5$ & 9 \\
\hline & activist] & & 5 & $3 / 4$ & 10 \\
\hline & & & 6 & $0 / 4$ & 0 \\
\hline & & & 7 & $3 / 5$ & 7 \\
\hline
\end{tabular}


Cite as: Montague, A. C., \& Eiroa-Orosa, F. J. (2018). In it together: Exploring how belonging to a youth activist group enhances well-being. Journal of Community Psychology, 46(1), 23-43. http://doi.org/10.1002/jcop.21914

\begin{tabular}{|c|c|c|c|c|c|}
\hline \multirow{2}{*}{$\begin{array}{l}\text { 2. Power in } \\
\text { numbers }\end{array}$} & \multirow{2}{*}{$\begin{array}{l}\text { 2.1 We can do it! } \\
\text { [believing we can }\end{array}$} & \multirow[t]{2}{*}{7} & 1 & \multirow{2}{*}{$\begin{array}{l}2 / 5 \\
4 / 5\end{array}$} & \multirow{2}{*}{$\begin{array}{l}3 \\
15\end{array}$} \\
\hline & & & 2 & & \\
\hline \multirow{12}{*}{$\begin{array}{l}\text { [Working with } \\
\text { others is more } \\
\text { impactful] }\end{array}$} & \multirow[t]{5}{*}{ make a difference] } & & 3 & $3 / 5$ & 4 \\
\hline & & & 4 & $2 / 5$ & 3 \\
\hline & & & 5 & $3 / 4$ & 3 \\
\hline & & & 6 & $2 / 5$ & 4 \\
\hline & & & 7 & $1 / 5$ & 2 \\
\hline & \multirow{7}{*}{$\begin{array}{l}2.2 \text { We did it! } \\
\text { [believing that we } \\
\text { have made a } \\
\text { difference] }\end{array}$} & \multirow[t]{7}{*}{7} & 1 & $5 / 5$ & 24 \\
\hline & & & 2 & $5 / 5$ & 22 \\
\hline & & & 3 & $4 / 4$ & 8 \\
\hline & & & 4 & $3 / 5$ & 4 \\
\hline & & & 5 & $3 / 4$ & 9 \\
\hline & & & 6 & $3 / 4$ & 22 \\
\hline & & & 7 & $4 / 5$ & 5 \\
\hline \multirow{18}{*}{$\begin{array}{l}\text { 3. Skilling up } \\
\text { [Learning life- } \\
\text { skills] }\end{array}$} & 3.1 Being seen & \multirow[t]{7}{*}{7} & 1 & $4 / 5$ & 8 \\
\hline & and heard & & 2 & $3 / 5$ & 8 \\
\hline & [Learning how to & & 3 & $4 / 4$ & 9 \\
\hline & express yourself, & & 4 & $3 / 5$ & 4 \\
\hline & and to do so in & & 5 & $2 / 4$ & 3 \\
\hline & \multirow[t]{2}{*}{ public] } & & 6 & $1 / 4$ & 4 \\
\hline & & & 7 & $5 / 5$ & 13 \\
\hline & 3.1.1 Brushing it & \multirow[t]{7}{*}{6} & 1 & $5 / 5$ & 4 \\
\hline & off & & 2 & $0 / 5$ & 0 \\
\hline & [Learning & & 3 & $2 / 4$ & 3 \\
\hline & resilience in the & & 4 & $3 / 5$ & 6 \\
\hline & face of public self- & & 5 & $1 / 4$ & 1 \\
\hline & \multirow[t]{2}{*}{ expression] } & & 6 & $2 / 4$ & 2 \\
\hline & & & 7 & $3 / 5$ & 4 \\
\hline & $3.3 \mathrm{No}$ 'I' in team & 7 & 1 & $4 / 5$ & 15 \\
\hline & [Learning how to & & 2 & $4 / 5$ & 6 \\
\hline & work effectively & & 3 & $4 / 4$ & 11 \\
\hline & with others] & & 4 & $5 / 5$ & 12 \\
\hline
\end{tabular}


Cite as: Montague, A. C., \& Eiroa-Orosa, F. J. (2018). In it together: Exploring how belonging to a youth activist group enhances well-being. Journal of Community Psychology, 46(1), 23-43. http://doi.org/10.1002/jcop.21914

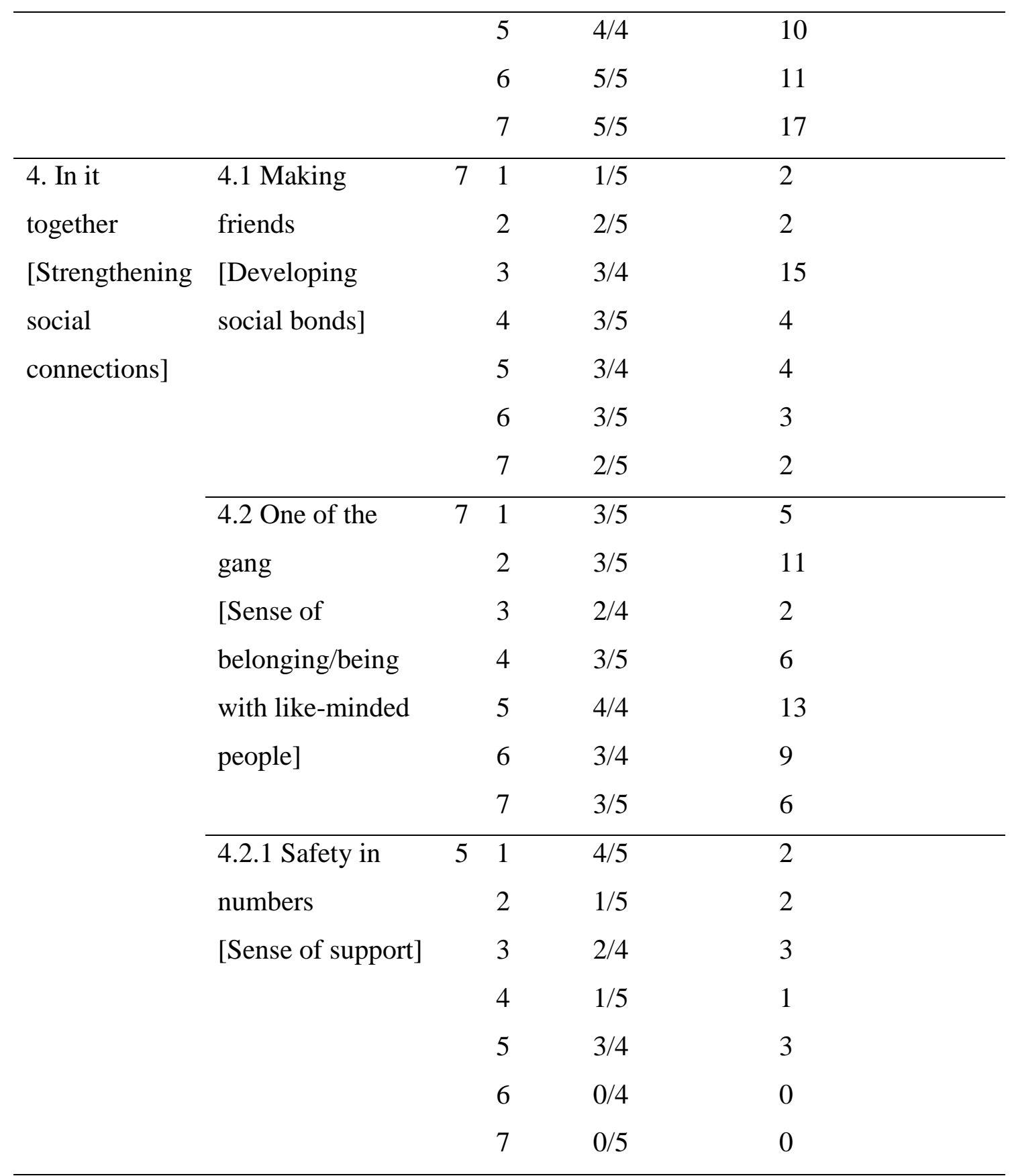

$\#=$ frequency of theme across data set $(n=7)$

\section{Themes}

\section{A place to go.}

This theme, which appeared a total of 180 (32.49\%) times across the focus groups, covers the ways in which participants describe how the Amnesty group provides a place 
Cite as: Montague, A. C., \& Eiroa-Orosa, F. J. (2018). In it together: Exploring how belonging to a youth activist group enhances well-being. Journal of Community Psychology, 46(1), 23-43. http://doi.org/10.1002/jcop.21914

for them to explore, express and develop their growing awareness of and interest in human rights issues.

\subsection{Opening eyes.}

Many participants describe a process of becoming aware of global human rights issues as a result of going to Amnesty meetings:

Lynne: Now we can understand how bad that is, like there are so many different, terrible things that can happen to people. And I just don't think I understood that before. I kind of just thought... I couldn't really empathize with it. But I think we understand it so we can see how that feels better.

Erica: Yeah. Perhaps see the reality of it almost (3)

Jessica (4) says 'I didn't realise, like, in some countries it's not even, like, basic human rights. I assumed by now, like, all countries would have at least, like, there wouldn't be torture going on but there is and that was quite shocking for me'. Louise (5) describes how, 'it's opened my eyes to what actually happens because I think a lot of it as well isn't reported in the news and I think it's really important'. Joanna (6) also explains how, 'it's opened my eyes to so many things'. Stephen (2) states, 'Something that I love about coming back to Amnesty and revisiting it is that the amount of knowledge that I have gained about contemporary issues from going to Amnesty meetings is really astounding'.

Developing awareness of human rights through their Amnesty group, leads to human rights issues becoming important in participants lives. Jessica (4) explains how 'I like the whole idea of peace and stuff'. Whilst Sally (1) says 'I kinda wanted, like, equality around the world so everyone has the same rights'. Sandra (3) thinks 'You know, basically, 'cos we can just exercise our rights to, like, the maximum level and some people can't and it's just unfair'. Some are even considering changing future aspirations because of being involved in the group: 
Cite as: Montague, A. C., \& Eiroa-Orosa, F. J. (2018). In it together: Exploring how belonging to a youth activist group enhances well-being. Journal of Community Psychology, 46(1), 23-43. http://doi.org/10.1002/jcop.21914

Tom: It sort of changed my mind like actually I might do a degree in something like international relations like I never would have thought that before ((laughs)).

Mark: Exactly the same. I started off sixth form wanting to be an architect. I ended up taking another year out, erm, in sixth form so I could change my direction, erm, and I'm now doing politics and international relations at uni, erm, and then from there on I want to work in human rights so it's completely changed my philosophy and life ambitions (1).

\subsection{Don't just sit there, do something!}

Focus group members expressed that it was important to actively do something about human rights and see attending the Amnesty group as the way to enable them to do this For Joanna (6),

'you are seeing bad stuff on TV all the time and you're like 'ah I wish something could be done about that' but then you come to Amnesty and you actually do something for it, so...'.

Jessica (4) says:

before I joined Amnesty I wanted to help people but I didn't know like how to but now I'm this group I can like get involved in the events... or when we send cards to people who are in jail like I wouldn't have been able to do that if I wasn't in the group.

Kathy (4) values the fact that 'you're taking action, it's not passive'. Jane (2) sums up the importance of taking action in the group:

And there is not much point hearing about it if you are not going to do something about it. So, the deal of making the difference is just trying to act upon stuff that you hear about and change it.

Some express the importance of taking action for others as a responsibility: 
Cite as: Montague, A. C., \& Eiroa-Orosa, F. J. (2018). In it together: Exploring how belonging to a youth activist group enhances well-being. Journal of Community Psychology, 46(1), 23-43. http://doi.org/10.1002/jcop.21914

Ruth: I feel like we need to sort of like give it back to the people who are in danger. And it's sort of like our duty to make sure that their lives are bearable.

Sandra: Yeah, that's the word, our duty. I feel like it's a duty (3).

\section{3. 'It's fun, frankly'.}

Not only has human rights activism become important in the lives of participants, it appears to be a source of deep interest and enjoyment, with a large amount of positive affective language expressed about group meetings. Sara (5) says, 'I think for me it's kind of like what I'm interested in, 'cos I didn't really come with anyone so I stayed for just, I don't know, I enjoy the topics that we do'. Tom (1) finds it 'a fun group to get involved with' whilst Katie (7) states:

It's fun, frankly. Erm because when you're like when you're designing things to go into a campaign or even when you're simply just writing a letter or something it's still, it's more of a social side, for example cos you're sat with your friends talking about stuff that's, you wouldn't necessarily talk about in normal conversation, erm so it's fun to sort of discuss them.

The experience of excitement is also present for some:

Kim: If we're all on board with like the same idea and like we're all like getting really excited about it.

Mark: Especially like the run up to events that we're putting on

Kim: Yeah

Mark: You feel so much more, erm

Kim: Like, energised

Mark: Energised, that's better than what I was going to say, erm, and you feel like you're like you come out of a meeting and you're you've got the energy (1) 
Cite as: Montague, A. C., \& Eiroa-Orosa, F. J. (2018). In it together: Exploring how belonging to a youth activist group enhances well-being. Journal of Community Psychology, 46(1), 23-43. http://doi.org/10.1002/jcop.21914

Jenny (7) explains why she likes attending meetings, 'I think for me it's mostly cos it's exciting and new'. Novelty in group meetings seems to be a factor in maintaining interest and enjoyment for others too. Louise (5) appreciates the fact that, 'we don't just have the same thing week after week which is good'. Lynne and Erica echo this sentiment:

Lynne: It's just interesting because it's a variety.

Erica: It keeps it new (3).

\section{Power in numbers.}

This theme, appearing 128 (23.10\%) times across all groups, describes participants' beliefs that, when working collectively with others, not only is it possible to succeed in their goals but also the belief that they have had a positive impact.

\subsection{We can do it.}

Participants frequently express the belief that working with others is more impactful than working on your own:

Stephen: And I suppose that is almost why we chose to join an organisation like Amnesty because as an individual it is very difficult to try and change the world around you. Like I said, to improve the quality of life of others. But as a united force we can sort of hit these problems head on which makes, muddies the water as it were.

Jake: Alone we are weak, together we are strong. That famous saying.

Jane: ((overlaps)) Yeah (2)

Louise (5) thinks, 'it feels like it means something more because rather than like one letter there's like thirty letters so you feel definitely that there is going to be more chance for change' whilst Kira (1) says, 'if you're doing it all together there's so much more awareness raised of the issue'. Saeed (6) states: 
Cite as: Montague, A. C., \& Eiroa-Orosa, F. J. (2018). In it together: Exploring how belonging to a youth activist group enhances well-being. Journal of Community Psychology, 46(1), 23-43. http://doi.org/10.1002/jcop.21914

The group I think has a louder voice than you being one individual. And because of that you can put in, er, it's a collective effort so you can get more done and that can create more of an impact.

\subsection{We did it.}

Many participants believe that they've had an impact, expressing satisfaction at their accomplishments:

Kim: And that bit, like, where after an event you hear the total of its all over and all the stress is over and you hear the total of how much you've raised and you're kind of like 'yeah we did that'

Mark: 'I did...We did that', yes! (1)

John (2) expresses a similar sense of accomplishment stating, 'looking back over the things we have done over the period of about two years we've done quite a lot actually and it was impressive and I felt really good about doing it'. A highlight for Ruth's activism (3) was getting responses from people in power:

So, I got letters, like envelopes from places like Buckingham Palace, I got one from there, Houses of Parliament and it made me feel like really special, like I was doing something. And I think that was probably the best experience of mine.

Getting results makes the challenging work and commitment worth it:

Toby: But maybe a thing that you don't enjoy always, maybe committing a lot of your time, but then when you look back you think 'Oh yeah that was great, I'm so glad I did that.'

Stephen: I agree with Toby. I think that it's definitely not really sort of a negative but it's a challenge that we have to face, is the issue of commitment especially with our exams, which are at the moment, which is, you know, it's very difficult to sort of balance these things. But it's when you achieve, when you achieve, er 
Cite as: Montague, A. C., \& Eiroa-Orosa, F. J. (2018). In it together: Exploring how belonging to a youth activist group enhances well-being. Journal of Community Psychology, 46(1), 23-43. http://doi.org/10.1002/jcop.21914

the commitment you know the commitment aspect as well as being able to fit in all your other stuff I see that as a success for me (2).

Joanna (6) states, 'You feel like your work hasn't gone to waste 'cos you do put hours and hours into it'. Similarly, Sally (1) states, 'When you put all the effort into, like, trying to teach someone about it and when they come out, like, changing their views that feels really nice.

Feeling as though you have achieved tangible success appears to re-enforce the feeling of being able to have impact (as discussed in previous sub-theme). After a successful campaign, Jenny (7) states:

it was the first campaign we did, the first creative thing we did, as a group and also, I feel like it was quite successful when we did it and I think that was the first moment I realised that you can impact other people's lives and kind of really make a change doing Amnesty work so I feel like that's a really big thing for me.

As a result of being part of her group Jane (2) has realised:

'You sort of realize it's not just the people, like people in seats and the politicians and the bankers who can change the world and who have the power over all the people. You actually can, just being a regular person, make a difference if there are enough of you that really want it enough'.

After working successfully with younger students Kim (1) states:

So, it was, like, you can see that real impact and you er you kind of know, well if I can do that with, er, twenty or twenty-five, like, year nines, then you know, what other impact can we have if we did that on a larger scale.

\section{Skilling-Up.}

This theme, with a total of $151(27.26 \%)$ appearances, relates to how youth group members develop skills. They seem to particularly have gained in confidence to express 
Cite as: Montague, A. C., \& Eiroa-Orosa, F. J. (2018). In it together: Exploring how belonging to a youth activist group enhances well-being. Journal of Community Psychology, 46(1), 23-43. http://doi.org/10.1002/jcop.21914

themselves, and moreover to do so in public settings. They also develop the key competencies of working in a team.

\subsection{Being seen and heard.}

Many participants reflected on how they had grown in confidence to express themselves.

Kim: I just kind of sat there kind of absorbing stuff but not really contributing anything whereas now I'd kind of, you know.

Mark: You're one of the most vocal people in the group

Kim: I never shut up. (1)

Erica (3) says, 'I used to be, people used to think I was quite shy and now I wouldn't say I'm a shy person. I know that it's okay to speak up' whilst fellow group member, Ruth (3) explains:

When I first joined, I was so shy I wouldn't speak to anybody. And if somebody would ask me a question I would give them a yes or no answer, if that. Otherwise I might just nod or shake my head. But now I'll talk to people more openly and I will like add onto my sentences a lot.

Kathy (4) considers herself, 'more confident in saying what I want to say cos I remember in year seven I never used to speak in the meetings but now I'm able to say my opinion and express myself'. Similarly, Fiona (7) states, 'Yeah, I really struggle with talking to people, it builds confidence up like it helps you like talk to different people that are different ages to you' and James (6) says, 'before it I used to be very shy, not talk too much except with my friends and actually when I got into Amnesty I became a lot more open to people. I started talking'. 
Cite as: Montague, A. C., \& Eiroa-Orosa, F. J. (2018). In it together: Exploring how belonging to a youth activist group enhances well-being. Journal of Community Psychology, 46(1), 23-43. http://doi.org/10.1002/jcop.21914

In addition to developing confidence to express themselves within the group, many participants expressed a sense of having gained in confidence to express themselves in public spheres:

Sally: I just went up to people and started talking to them about Amnesty and then you just realise that you can't really be scared of anyone really

Mark: You just get on with it (1)

Kim (1) states, 'Well, you kind of realise if I can do at Amnesty group, I can, it gives you confidence to like speak out more in other places'. Stephen (2) states that the group, 'has been pushing us to do a lot more public speaking, which is always great and character building' whilst fellow group member Jane (2) agrees that 'doing public speaking is a real confidence boost'. Describing one particular campaign Erica (3) says: I had to go around and ask people 'Will you please sign this' and talk to them about it and explain a little bit about Amnesty and what it is doing for Brazil. And I think for me that was quite useful because it meant I was, it meant I did speak to people and it showed me that it's okay to speak out and I could go out to people and talk to them.

\subsubsection{Brushing it off}

The act of expressing yourself publicly requires some group members to push themselves to go outside their comfort zones and deal with potential negative reactions from others:

Matt: Sometimes you need to overcome your fears I think. Some people might public speaking issues let's say and but you want to do it so you need to like fight with yourself and get out there and do it (6).

Mark (1) describes a similar sentiment:

I was, like, not in my shell before I joined Amnesty but I wasn't really 'out there' and then I did candy man adverts and that was the start of it really. Erm, I, every year we 
Cite as: Montague, A. C., \& Eiroa-Orosa, F. J. (2018). In it together: Exploring how belonging to a youth activist group enhances well-being. Journal of Community Psychology, 46(1), 23-43. http://doi.org/10.1002/jcop.21914

do a candy cane sales and we make a video advert and I was the candy man walking around with this big candy cane around school selling, throwing candy canes to people, erm, ((general laughter)). And from there I've found my confidence has grown a lot.

Jane (2) found that 'standing out, sort of stepping out' felt a little 'defiant' but concluded that 'being defiant is definitely a good thing'.

As a result, many participants appear to develop resilience in overcoming potential negative reactions from others such as doing school assemblies:

Katie: But you also get to a certain point where you just sort of like 'right I need to do this' you sort of suck it up and you've got

Jenny: You deal with it

Katie: You've got that level of sort emergency confidence

Phil: ((in overlap)) You realise it's not the end of the world

Katie: Yeah

Similarly, describing an embarrassing public dance routine as part of a publicity stunt, Annie (4) states, 'I mean afterwards I came off laughing at myself and how bad I was at dancing'. A different group shared a similar experience:

Sally: Yeah, some people really hate Amnesty and erm and it kind of divides opinion a bit and you do get a bit of abuse but erm you kind of, it's kind of like you deal with that and erm...

Kira: Brushing it off

Katie: yeah

Sally: Yeah brushing it off and just being able to go up to someone and be like 'here you go. Here's what I believe in. I don't, I hope you believe in it too but if you don't it's not the end of the world' (1). 
Cite as: Montague, A. C., \& Eiroa-Orosa, F. J. (2018). In it together: Exploring how belonging to a youth activist group enhances well-being. Journal of Community Psychology, 46(1), 23-43. http://doi.org/10.1002/jcop.21914

\subsection{There's no 'I' in team.}

Learning how to effectively work with others was frequently mentioned. For example, learning to listen to and respect opposing views was commonly raised. Fiona (7) states, 'you, like, learn to listen to their ideas as well as yours, like, not just taking yours into account but other people's as well and then you can like all work together'. Sara and Michael say:

Sara: Well it's about respect as well cos we erm, talk we erm like disagree but without stepping on other people's toes kind of, like being really nice

Michael: Like it's good to express your opinion but you've got to listen to other people carefully because, erm, they might be offended otherwise or something (5).

There is some disagreement about the pros and cons of conflict within the group, with Kira (1) stating that good meetings are when, 'everyone agrees with each other, there's, like, no conflict' whilst Stephen (2) sees divided opinion as a good thing saying, 'that's something that I think is actually very healthy to have as a group, because it reminds us that we are individuals and that we're not all just bound to the same beliefs'. Annie (4) states, 'Yeah, arguments are non-existent. I mean it's, it wouldn't, if we do disagree on something we'll come to a compromise'. When Mark (1) disagreed on a decision made by the group, 'I still got behind it and was, like, 'yeah it's brilliant' otherwise I wouldn't be here today. But it's, yeah, democracy'.

Everyone having a valued role appears important to group work especially one that plays to peoples' talents. Kim (1) describes how 'you each have kind of a purpose... you're going there with kind of a role that you kind of feel valued for'. Stephen (2) states that 'as a community we all bring our different strengths which helps provide enormous infrastructure to this community'. Ruth and Sandra (3) agree that, 'We all sort of get to 
Cite as: Montague, A. C., \& Eiroa-Orosa, F. J. (2018). In it together: Exploring how belonging to a youth activist group enhances well-being. Journal of Community Psychology, 46(1), 23-43. http://doi.org/10.1002/jcop.21914

chip in and I think that's how it's so successful because we learn how to work as a team so well (Ruth). Yeah, we kind of rely on each other (Sandra).

Pulling your weight and sharing the workload fairly is considered an important part of teamwork:

Hayley: so, no one person is doing a lot of work, it's more spread out and then, erm, and then you just come back with the stuff next week

Annie: We're all willing to do work for it which I like it means that you don't get one person who never wants to do anything and it means that we have, sort of, everyone splits it evenly (4)

Patricia (4) from the same group says, 'if we don't do it we feel like we're letting the group down'. Phil and Katie talk about the importance of dividing up work equally:

Phil: It shares the load really like it reduces the amount of work you've got to do as an individual. Makes it easier.

Katie: And especially like during like exams and things if you have if you're that one person and you have to do some posters and write a letter as well whereas if there's two of you, you've shared the workload (4)

\section{In it together.}

This theme, featuring a total of 95 appearances (17.15\%), explores the way being involved in the Amnesty group develops and deepens social connections..

\subsection{Making friends.}

The formation of strong social relationships appears to be a salient feature of group membership:

Joanna: 'I didn't know him before, erm, Amnesty all that much I don't think and then now we're good friends I guess'.

Matt: 'Pretty much' (6) 
Cite as: Montague, A. C., \& Eiroa-Orosa, F. J. (2018). In it together: Exploring how belonging to a youth activist group enhances well-being. Journal of Community Psychology, 46(1), 23-43. http://doi.org/10.1002/jcop.21914

Other groups express the same thing, such as Stephen (2) who states, 'We have made lasting friendships in this group' and Erica (3) thinks, 'it just makes us closer together because we are used to spending so much more time together now because of Amnesty'.

Many participants welcomed the opportunity to meet new people outside their usual social circle:

Louise: it's nice to be able to like interacting with other people that don't, because I only have one set of people in my class, I don't move around with other people so going to a different place and like getting out a bit more of the classroom is nice.

Describing a similar experience Tom (1) says, 'you get out a bit more, you actually sort of meet and talk to new people, get to know people'. Getting to mix with members of different ages was also emphasised:

Sandra: But when we come to Amnesty it's not like 'I'm year thirteen and they're year ten. It's like we are all in the same year.

Erica: Yeah. It is. It's kind of taking the segregation of years away. (3)

Members of other focus groups felt the same. Saeed (6) states, 'there are also students from year seven all the way to year eleven in Amnesty and sometimes you get, erm, to see their perspective or just maybe talk to them which doesn't happen very often'. According to Hayley (4):

there's different year groups, it's not just one year group it's like spread out so, like, you get to interact with people you wouldn't normally interact with I suppose and as, erm, also like in that way that you find new people really.

Katie (7), sees the group as, 'Almost like bridging the gap between our year and the years below'. 
Cite as: Montague, A. C., \& Eiroa-Orosa, F. J. (2018). In it together: Exploring how belonging to a youth activist group enhances well-being. Journal of Community Psychology, 46(1), 23-43. http://doi.org/10.1002/jcop.21914

\subsection{One of the gang.}

Being part of a group of people who share your values was important to participants. Louise (5) states that the group gives her, 'the sense that you're not the only one who feels like this way and that there are other people who share similar ideas and want to do the same as you'. James (6) says, 'I just keep on going back as much as I can because I feel like I can go and meet the same people with the same ideas that want to make a change to the world'. Laura (7) thinks:

I enjoy like discussing like other's people's problems and trying to like to work out ways to help them but like with like-minded people rather than my friends cos a lot of my friends disagree with how like I think we should help other people so it's good to have a group of people who agree with how I feel.

Jane (2) has realised that, 'you're not the only person who really has an issue with some of the things going on in the world. That there actually are people with common views'.

This feeling of being part of a group of like-minded people appears to give rise to a strong sense of community. Ruth (3) describes this as, 'it's all part of a team, sort of like a family. And everyone works together'. James (6) describes how, 'it just feels kind of like a family sometimes' and Joanna (6) from the same group elaborates:

Yeah, because you do go in the same place with the same people so it's a bit like, erm, Ms Smith's classroom is our house and we just go there and ((laughs)), I don't know, cos it's not like, yeah, we do Amnesty stuff but at the same time we get to know each other through it, so it does feel like family in a way.

Louise (5) states it more explicitly, 'You feel you belong I suppose which is quite important for teenagers I guess'. 
Cite as: Montague, A. C., \& Eiroa-Orosa, F. J. (2018). In it together: Exploring how belonging to a youth activist group enhances well-being. Journal of Community Psychology, 46(1), 23-43. http://doi.org/10.1002/jcop.21914

For some this sense of belonging goes beyond the immediate group to the Amnesty organisation's wider national and global membership. Jake (2) for example says, 'If you put enough people with an insignificant difference together eventually I feel we will have a significant difference. So, we are part of... we are a very small part of a bigger picture'. Sara (5) states, 'we get feedback ... about how everyone around the country's doing the same thing as us at the same time so we kind of know we're all involved together'. After going to a demonstration organised by Amnesty, Joanna (6) feels more connected to the organisation's wider activist community:

I think when we're in our school, it feels sort of like we are alone in a way because we don't get to meet with other people from other groups regularly and we also kids we don't often realise that there is people like you, older than us that are actually doing this and to go there and see like tonnes of people that are screaming their lungs out chanting and everything it's just, wow!

Similarly, meeting members of other Amnesty youth groups at a conference Jane (2) describes how. 'One of them said to me, 'It's really odd because I don't know anything about you and we've only known each other for, like, a few hours but we have this one thing in common'.

\subsubsection{Safety in numbers.}

Working in a group with like-minded others also appears to give rise to a feeling of being supported for some of the participants. Ruth (3) feels that, 'everyone is there for everybody else no matter what' and other members of her group agree:

Ruth: I think it gives us, erm, more confidence as well because I think if we were on our own we wouldn't do half the stuff we do.

Erica: Yeah.

Lynne: We'd be embarrassed. 
Cite as: Montague, A. C., \& Eiroa-Orosa, F. J. (2018). In it together: Exploring how belonging to a youth activist group enhances well-being. Journal of Community Psychology, 46(1), 23-43. http://doi.org/10.1002/jcop.21914

Erica: Yeah, I think we kind of help each other, don’t we? (3)

Stephen (2) says,' It's extremely important, I think, at least for me, that we can work within a group 'cos it gives everyone a sense of support. Kira (1) states, 'you know that there are gonna be twenty, at least twenty, other people who are, erm, who are going to be there with you saying, 'Yeah we should fight for this person'.

\section{Discussion}

The themes and sub-themes we identified can be related to both broader literature in psychology and the specific youth activism research reviewed in the introduction in several ways. Our 'Place to go' theme talked about how the Amnesty group provided a space to explore, express and develop participants growing awareness of and interest in human rights issues. Two of its sub-themes 'Opening eyes' and 'Don't just sit there, do something', illustrated the process by which participants become aware of and develop a passion for taking action to promote and defend human rights suggesting a link in the broader literature with theory on both identity development and values (e.g. Marcia, 1966; Pancer et al, 2007; Sheldon \& Elliot, 1999). Adolescence is a key phase of identity consolidation and the extent to which participants in this study decide that human rights issues are important to them suggest a link to 'Identity Achievement', the most developed phase of Marcia's (1966) spectrum of identity development. At this stage a person 'commits to a particular set of values, priorities, or interpersonal style after a period of exploration' (Pancer et al., 2007, p. 746). Participants in the current study describe developing an awareness of global issues and express wanting to have a role in improving society, suggesting that they are developing socio-political identity (Watts et al., 2003) or as Kirshner, 2009, conceptualises it, civic identity. For some, the latter is the same as moral identity (Youniss, Mclellan, \& Mazer, 2001), though Kirshner (2009) argues that civic identity has the specific component of tackling causes that directly affect one's own 
Cite as: Montague, A. C., \& Eiroa-Orosa, F. J. (2018). In it together: Exploring how belonging to a youth activist group enhances well-being. Journal of Community Psychology, 46(1), 23-43. http://doi.org/10.1002/jcop.21914

life. Pearce and Larson (2006) also argue that, to engage young people, activism programmes need to focus on issues directly affecting the lives of the participants.

In the current study, participants displayed high levels of engagement but were unlikely to be personally affected by the human rights issues they were addressing which challenges this assumption. Related to this point is the potential link between this theme and the process of developing critical consciousness whereby people learn to critically analyse injustices in their socio-political context (critical reflection) and act to change it (critical action) which could potentially map our 'Opening Eyes' and 'Don't just sit there, do something!' sub-themes respectively (Freire, 1973). However, most critical consciousness research has tended to see this process as being particularly beneficial for marginalized groups directly affected by unjust social conditions (e.g. Diemer \& Li, 2011) which again wasn't necessarily the case for the participants of this study. However, Watts, Diemer and Voight (2011) argue that the development of critical consciousness can also be of benefit to more privileged young people too.

Participants in this study appear to be acting in line with their values in that human rights, attending group meetings and taking action have become important to them, suggesting a link to Sheldon and Elliot's (1999) Self-Concordance model. Goals that are values-concordant have greater chance of being accomplished and lead to greater well-being benefits.

In relation to, 'It's fun, frankly', our third sub-theme of 'A place to go', showing high levels of interest and enjoyment suggests that participants are intrinsically motivated, i.e. taking part in an activity because it is inherently enjoyable, interesting or satisfying, an important factor influencing well-being (Ryan \& Deci, 2000). Kashdan and Silvia (2009) agree, adding that curiosity and interest are the "core of intrinsically motivated action' (p.367). They also emphasise that curiosity is associated with seeking out novelty, 
Cite as: Montague, A. C., \& Eiroa-Orosa, F. J. (2018). In it together: Exploring how belonging to a youth activist group enhances well-being. Journal of Community Psychology, 46(1), 23-43. http://doi.org/10.1002/jcop.21914

which was also emphasised by participants in this study who thought that variety in their group meetings was important. Hunter and Csikszentmihalyi's (2003) study of 'interested' adolescents found that the experience of chronic interest was associated with higher levels of well-being and suggest that enhancing levels of interest could have particular benefits for teenagers.

Regarding the specific youth activism research outlined in the introduction, our 'Place to go' theme can be related in a number of ways. For example, Pearce and Larson's (2006) study following youth activists' journey from extrinsic to intrinsic motivation, showed how an initial motivation to get school credits developed into the development of a personal connection to a cause. This led to youth activists becoming intrinsically motivated with the experience of fun, interest and excitement being cited as factors in their commitment. Whilst some in the current study were already aware of and motivated by human rights issues, many came to the Amnesty group due to peer influence rather than pre-existing interest in human rights, a passion which developed on the way mirroring Pearce and Larson's (2006) findings. Harré (2007) describes activism as an 'identity project' and identified experiences of stimulation and integrity amongst youth activists which can be likened to the development of interest and setting value-concordant goals in the current study. Similarly, the development of socio-political awareness has been identified as an outcome of youth activism mirroring participants comments in the current study of having their eyes opened to global human rights issues (Kirshner, 2009; Morsillo \& Prilleltensky, 2007; Watts et al., 2003).

'Power in numbers' and its sub-themes 'We can do it!' and 'We did it!' highlighted the ways in which participants felt that they could, and in fact, did achieve impact. In the broader literature, this suggests a link to Bandura's theories on efficacy, concerning people's beliefs in their capabilities to achieve goals (e.g. Bandura, 1997). 
Cite as: Montague, A. C., \& Eiroa-Orosa, F. J. (2018). In it together: Exploring how belonging to a youth activist group enhances well-being. Journal of Community Psychology, 46(1), 23-43. http://doi.org/10.1002/jcop.21914

High levels of self-efficacy have been linked to a number of positive well-being outcomes such as sense of control, self-regulation and physical health (Maddux, 2009). However, given the group members' beliefs in the current study that they would have more impact when working with others, a sense of collective efficacy or 'a group's shared belief in its conjoint capabilities to organize and execute the courses of action required to produce given levels of attainments' (Maddux, 2009, p.477) seems more relevant here. According to collective efficacy research, high levels of perceived collective efficacy can lead to greater staying power when facing setbacks and an increased likelihood of achieving goals (Bandura, 2000). Particularly relevant for the current study, the role that collective efficacy plays in achieving social change is beginning to be interrogated (FernandezBallesteros, Diez-Nicolas, Caprara, Barbaranelli, \& Bandura, 2002). Not only did participants feel that collectively they can have an impact, they also feel as though they have had an impact, and frequently express a sense of accomplishment. Whilst researchers believe it is likely that having high levels of efficacy, whether personal or collective, could lead to greater levels of accomplishment (Bandura, 2000), it's worth noting that perception of success is highly subjective, depending on the self-beliefs of individuals (Maddux, 2009). It is beyond the remit of this study to interrogate whether impact was genuinely achieved. What is more important is that participants believed they were successful which appeared to further reinforce efficacy beliefs. This is consistent with research indicating that efficacy beliefs are enhanced by the belief that success was achieved as a result of our own efforts rather than external factors (Maddux, 2009).

Again, with regard to youth activism research studies reviewed previously and our 'Power in numbers' theme, Pearce and Larson (2006) describe a similar sense of collective efficacy in their youth activism research whilst Harré (2007) also describes strong feelings of efficacy amongst youth activists but doesn't discuss whether this was 
Cite as: Montague, A. C., \& Eiroa-Orosa, F. J. (2018). In it together: Exploring how belonging to a youth activist group enhances well-being. Journal of Community Psychology, 46(1), 23-43. http://doi.org/10.1002/jcop.21914

collective or personal. Morsillo and Prilleltensky (2007) conceptualise efficacy as hopefulness, i.e. 'young people's perception about their ability to make a change' (p.732) and see noticeable increases of this construct in the young people in their study. Kirshner (2009) also highlighted the perception among youth activists that working with others would yield a greater impact than working alone, albeit called collective agency in their study. This study hopes to contribute to the distinct qualities of collective efficacy versus self-efficacy as recommended by researchers in the field (Maddux, 2009). That said, it should be noted that self and collective efficacy are clearly linked since, 'a collection of inveterate self-doubters is not easily forged into a collectively efficacious force' (Bandura, 1997, p.480).

Our 'Skilling-Up' theme talked about skills-building as part of participants' experience of being part of an activist group, such as developing communication skills ('Being seen and heard'), bouncing back when dealing with negative reactions from others and team work (No 'I' in team). This theme also appears in youth activism research literature with Morsillo and Prilleltensky (2007) highlighting the opportunity for selfexpression as important for youth activists and expressing oneself in public being conceptualised as assertiveness. They also emphasise that 'group effectiveness' (p. 732) was developed as a skill. Youth activists in Kirshner's (2009) study learned how to make decisions collectively and make the most of each other's strengths and Harré (2007) mentions learning new skills as leading to the experience of efficacy.

Brushing off and bouncing back from setbacks, i.e. developing resilience, is an important factor impacting well-being as it relates to an individual's ability to deal positively and adaptively to stressful situations (Tugade \& Fredrickson, 2004). However, in the context of this study, resilience was only referred to in reference to coping with potential negative reactions from others, the theme 'Brushing it off', so it is not possible 
Cite as: Montague, A. C., \& Eiroa-Orosa, F. J. (2018). In it together: Exploring how belonging to a youth activist group enhances well-being. Journal of Community Psychology, 46(1), 23-43. http://doi.org/10.1002/jcop.21914

to gauge whether participants developed resilience in other realms of their lives. A link to previously identified themes can also be found here in that high levels of efficacy and intrinsic motivation appear to encourage individuals to bounce back from challenges more effectively (Bandura, 1997; Ryan \& Deci, 2000).

'In it together' described participants' experiences of strong social bonds within the group. Having strong inter-personal connections is considered one of the major predictors of psychological well-being, with 'relatedness' as one of Ryan and Deci's (2000) three innate psychological needs in self-determination theory. Baumeister and Leary (1995) argue that the need to belong, that is, the need to form and maintain interpersonal relationships, is a key factor in human motivation. Being with like-minded people as a component of establishing friendships is in line with McMillan's (1996) view that 'bonding begins with the discovery of similarities' (p.321).

'In it together' also mirrors findings in youth activism research with Pearce and Larson (2006) also citing peer support as a key factor behind motivation. Harré (2007), Kirshner (2009) and Morsillo and Prilleltensky (2007) all reference a strong sense of belonging amongst youth activists whilst having a sense of 'social support' was one indicator of good emotional adjustment amongst activists in Pancer et al.'s (2007) study, mirroring our 'Safety in numbers theme'. Watkins et al. (2007) showed how developing relationships with people one doesn't normally interact with helped to 'bridge intergroup difference' (p.380). This links to the current study which appears to have helped young activists interact with people that they usually do not mix with, albeit with students from different year groups as opposed to different ethnic backgrounds as in Watkins et al.'s (2007) study.

\section{Conclusion}


Cite as: Montague, A. C., \& Eiroa-Orosa, F. J. (2018). In it together: Exploring how belonging to a youth activist group enhances well-being. Journal of Community Psychology, 46(1), 23-43. http://doi.org/10.1002/jcop.21914

This study explored the relationship between youth activism and psychological well-being and our findings suggest numerous psychological benefits to being a youth activist. It has several implications. It has attempted to make a small contribution to addressing the over-emphasis on service giving activities such as volunteering in existing activism and youth civic engagement research and, as such, hopes to add weight to the argument that activism is a different construct to volunteering worth studying in its own right (Gilster, 2012). It supports concepts found in existing youth activism research, such as intrinsic motivation, identity, values, social connections, efficacy and skills-building (e.g. Harré, 2007; Morsillo and Prilleltensky, 2007; Pearce \& Larson, 2006) but also challenges the perception argued in many studies that one has to be personally affected by the issues one is campaigning on to get well-being benefits from activism (e.g. Kirshner, 2009; Pearce \& Larson, 2006) since the participants in this study were advocating for the rights of others not themselves. Community psychologists working with youth may find these results useful for social change projects. Creating a group environment that enables young people to develop their knowledge and individual passions, work collectively on issues of mutual interest, build skills and increase social connections, may not only lead to tangible social change but could have also significant psychological benefits for the young people involved.

This study has its limitations. It used a small sample size and focus groups with children can have their limitations. It's possible, for example, that some participants felt intimidated in a group setting which may hamper interaction or they may copy themes raised by others in the group if not relaxed enough to offer their own opinion (Lewis, 1992). As previously outlined, the study was also linked to the researcher's professional life which could also have influenced findings (Creswell, 2014). It should also be noted that the focus of this study was on the individual well-being outcomes of being involved 
Cite as: Montague, A. C., \& Eiroa-Orosa, F. J. (2018). In it together: Exploring how belonging to a youth activist group enhances well-being. Journal of Community Psychology, 46(1), 23-43. http://doi.org/10.1002/jcop.21914

in an activist group. As such, it does not consider the social context of the participants nor look at well-being at group or community-level.

More studies are needed before these findings can be generalised. Future research could replicate this study using larger sample sizes or different qualitative approaches, such as semi-structured interviews or participatory action research. It could also be useful to map these findings onto dominant youth development models such as Positive Youth Development (PYD; Larson, 2000). According to this model, well-functioning young people display the presence of 6 'C's: competence, confidence, character, caring, connection and contribution and accordingly Sherrod (2007) has already argued that activism is an expression of PYD. Additionally, there were a few potential candidate themes in the current study that didn't make the final cut in the context of our study but could be worthy of further investigation in their own right. These include the negative well-being outcomes of being a youth activist, the relationship between the adult leader and youth group members and how being part of the Amnesty group is perceived to help counter negative perceptions of teenagers. Finally, it could be interesting to explore in more detail how working on rights issues you are personally affected by versus advocating for others rights may or may not have specific well-being outcomes.

According to our study, being involved in activism as a teenager can be beneficial to the personal development and psychological well-being of those involved and, as such, should be of greater interest to social movement organizers and activists (Louis, 2009) and also relevant policymakers. Similarly, we believe that academic research on this topic, whilst retaining its rigor, should be committed to collective action as a form of social change. An interesting outcome would be the development of forms of activism as group-level interventions, benefiting not only individuals but also society as a whole. 
Cite as: Montague, A. C., \& Eiroa-Orosa, F. J. (2018). In it together: Exploring how belonging to a youth activist group enhances well-being. Journal of Community Psychology, 46(1), 23-43. http://doi.org/10.1002/jcop.21914

\section{Acknowledgements}

We would like to thank colleagues at Amnesty International UK who were behind the project all the way. A final thanks must go to the youth activists interviewed who were responsive, fun and inspiring. Dr. Eiroa-Orosa has received funding from the European Union's Framework Programme for Research and Innovation Horizon 2020 (2014-2020) under the Marie Sklodowska-Curie Grant Agreement No 654808.

\section{References}

Bandura, A. (1997). Self-efficacy: the exercise of control. New York, NY: W. H. Freeman.

Bandura, A. (2000). Exercise of Human Agency Through Collective Efficacy. Current Directions in Psychological Science, 9(3), 75-78. https://doi.org/10.1111/14678721.00064

Baumeister, R. F., \& Leary, M. R. (1995). The need to belong: Desire for interpersonal attachments as a fundamental human motivation. Psychological Bulletin, 117(3), 497-529. https://doi.org/10.1037/0033-2909.117.3.497

Braun, V., \& Clarke, V. (2006). Using thematic analysis in psychology. Qualitative Research in Psychology, 3(2), 77-101. https://doi.org/10.1191/1478088706qp063oa

Christens, B. D. (2012). Toward Relational Empowerment. American Journal of Community Psychology, 50(1-2), 114-128. https://doi.org/10.1007/s10464-0119483-5

Christens, B. D., Winn, L. T., \& Duke, A. M. (2016). Empowerment and Critical Consciousness: A Conceptual Cross-Fertilization. Adolescent Research Review, 1(1), 15-27. https://doi.org/10.1007/s40894-015-0019-3

Creswell, J. W. (2014). Research Design: Qualitative, Quantitative, and Mixed Methods 
Cite as: Montague, A. C., \& Eiroa-Orosa, F. J. (2018). In it together: Exploring how belonging to a youth activist group enhances well-being. Journal of Community Psychology, 46(1), 23-43. http://doi.org/10.1002/jcop.21914

Approaches. Research design Qualitative quantitative and mixed methods approaches (4th ed.). London, UK: SAGE.

Di Martino, S., Eiroa-Orosa, F. J., \& Arcidiacono, C. (2017). Community Psychology’s Contributions on Happiness and Well-being: Including the Role of Context, Social Justice, and Values in Our Understanding of the Good Life. In The Routledge International Handbook of Critical Positive Psychology. London, UK: Routledge.

Diemer, M. A., \& Li, C.-H. (2011). Critical Consciousness Development and Political Participation Among Marginalized Youth. Child Development, 82(6), 1815-1833. https://doi.org/10.1111/j.1467-8624.2011.01650.x

Downton, J., \& Wehr, P. (1998). Persistent Pacifism: How Activist Commitment is Developed and Sustained. Journal of Peace Research, 35(5), 531-550. https://doi.org/10.1177/0022343398035005001

Eigner, S. (2001). The relationship between "protecting the environment" as a dominant life goal and subjective well-being. In P. Schmuck \& K. M. Sheldon (Eds.), Life goals and well-being: towards a positive psychology of human striving (pp. 182201). Kirkland, WA: Hogrefe \& Huber.

Eisenberg, N., \& Fabes, R. A. (1998). Prosocial development. In N. Eisenberg (Ed.), Handbook of child psychology: Vol. 3. Social, emotional, and personality development (5th ed., pp. 701-778). New York City: Wiley. https://doi.org/10.1002/9780470147658.chpsy0311

Ekman, J., \& Amnå, E. (2012). Political participation and civic engagement: Towards a new typology. Human Affairs, 22(3), 283-300. https://doi.org/10.2478/s13374-0120024-1

Fernandez-Ballesteros, R., Diez-Nicolas, J., Caprara, G. V., Barbaranelli, C., \& Bandura, A. (2002). Determinants and Structural Relation of Personal Efficacy to Collective 
Cite as: Montague, A. C., \& Eiroa-Orosa, F. J. (2018). In it together: Exploring how belonging to a youth activist group enhances well-being. Journal of Community Psychology, 46(1), 23-43. http://doi.org/10.1002/jcop.21914

Efficacy. Applied Psychology, 51(1), 107-125. https://doi.org/10.1111/14640597.00081

Freire, P. (1973). Education for critical consciousness. New York City, NY: Seabury.

Gilster, M. E. (2012). Comparing neighborhood-focused activism and volunteerism: psychological well-being and social connectedness. Journal of Community Psychology, 40(7), 769-784. https://doi.org/10.1002/jcop.20528

Ginwright, S. (2003). Youth Organizing: Expanding Possibilities for Youth Development. Occasional Papers Series on Youth Organizing, 3.

Harré, N. (2007). Community service or activism as an identity project for youth. Journal of Community Psychology, 35(6), 711-724. https://doi.org/10.1002/jcop.20174

Harré, N., Tepavac, S., \& Bullen, P. (2009). Integrity, efficacy and community in the stories of political activists. Qualitative Research in Psychology, 6, 330-345. https://doi.org/10.1080/14780880903324764

Hart, D., \& Carlo, G. (2005). Moral Development in Adolescence. Journal of Research on Adolescence, 15(3), 223-233. https://doi.org/10.1111/j.1532-7795.2005.00094.x

Heary, C. M. (2002). The Use of Focus Group Interviews in Pediatric Health Care Research. Journal of Pediatric Psychology, 27(1), 47-57. https://doi.org/10.1093/jpepsy/27.1.47

Hunter, J. P., \& Csikszentmihalyi, M. (2003). The Positive Psychology of Interested Adolescents. Journal of Youth and Adolescence, 32(1), 27-35. https://doi.org/10.1023/A:1021028306392

Kashdan, T. B., \& Silvia, P. J. (2009). Curiosity and Interest: The Benefits of Thriving on Novelty and Challenge. In S. J. Lopez \& C. . Snyder (Eds.), Handbook of Positive Psychology (pp. 367-375). New York, NY: Oxford University Press. https://doi.org/10.1093/oxfordhb/9780195187243.013.0034 
Cite as: Montague, A. C., \& Eiroa-Orosa, F. J. (2018). In it together: Exploring how belonging to a youth activist group enhances well-being. Journal of Community Psychology, 46(1), 23-43. http://doi.org/10.1002/jcop.21914

Kieffer, C. H. (1984). Citizen Empowerment. Prevention in Human Services, 3(2-3), 936. https://doi.org/10.1300/J293v03n02_03

Kirshner, B. (2007). Introduction: Youth Activism as a Context for Learning and Development. American Behavioral Scientist, 51(3), 367-379. https://doi.org/10.1177/0002764207306065

Kirshner, B. (2009). "Power in Numbers": Youth Organizing as a Context for Exploring Civic Identity. Journal of Research on Adolescence, 19(3), 414-440. https://doi.org/10.1111/j.1532-7795.2009.00601.x

Klar, M., \& Kasser, T. (2009). Some Benefits of Being an Activist: Measuring Activism and Its Role in Psychological Well-Being. Political Psychology, 30(5), 755-777. https://doi.org/10.1111/j.1467-9221.2009.00724.x

Larson, R. W. (2000). Toward a psychology of positive youth development. American Psychologist, 55(1), 170-183. https://doi.org/10.1037/0003-066X.55.1.170

Larson, R. W., \& Hansen, D. (2005). The development of strategic thinking: Learning to impact human systems in a youth activism program. Human Development, 48, $327-$ 349. https://doi.org/10.1159/000088251

Lewis, A. (1992). Group Child Interviews as a Research Tool. British Educational Research Journal, 18(4), 413-421. https://doi.org/10.1080/0141192920180407

Louis, W. R. (2009). Collective Action-and Then What? Journal of Social Issues, 65(4), 727-748. https://doi.org/10.1111/j.1540-4560.2009.01623.x

Maddux, J. E. (2009). Self-Efficacy: The Power of Believing You Can. In S. J. Lopez \& C. R. Snyder (Eds.), The Oxford Handbook of Positive Psychology (2 ed.) (pp. 367374). New York, NY: Oxford University Press. https://doi.org/10.1093/oxfordhb/9780195187243.013.0031

Marcia, J. E. (1966). Development and validation of ego-identity status. Journal of 
Cite as: Montague, A. C., \& Eiroa-Orosa, F. J. (2018). In it together: Exploring how belonging to a youth activist group enhances well-being. Journal of Community Psychology, 46(1), 23-43. http://doi.org/10.1002/jcop.21914

Personality and Social Psychology, 3(5), 551-8.

Mccarthy, J. J. (1981). Research on Neighbourhood Activism. South African Geographical Journal, $\quad$ 63(2), 107-131. https://doi.org/10.1080/03736245.1981.10559646

McMillan, D. W. (1996). Sense of community. Journal of Community Psychology, 24(4), 315-325. $\quad$ https://doi.org/10.1002/(SICI)1520-6629(199610)24:4<315::AIDJCOP2>3.0.CO;2-T

Meier, S., \& Stutzer, A. (2008). Is volunteering a reward in itself? Economica, 75(297), $39-59$.

Montague, A. C., \& Eiroa-Orosa, F. J. (2017). Exploring the Role of Engagement on Well-Being and Personal Development: A Review of Adolescent and Mental Health Activism. In N. J. L. Brown, T. Lomas, \& F. J. Eiroa-Orosa (Eds.), The Routledge International Handbook of Critical Positive Psychology (pp. 437-446). London, UK: Routledge.

Morsillo, J., \& Prilleltensky, I. (2007). Social action with youth: Interventions, evaluation, and psychopolitical validity. Journal of Community Psychology, 35(6), 725-740. https://doi.org/10.1002/jcop.20175

Pancer, S. M., Pratt, M., Hunsberger, B., \& Alisat, S. (2007). Community and political involvement in adolescence: What distinguishes the activists from the uninvolved? Journal of Community Psychology, 35(6), 741-759. https://doi.org/10.1002/jcop.20176

Pearce, N., \& Larson, R. (2006). How teens become engaged in youth development programs: The process of motivational change in a civic activism organization. Applied Developmental Science, 10(3), 121-131. https://doi.org/10.1207/s1532480xads1003_2 
Cite as: Montague, A. C., \& Eiroa-Orosa, F. J. (2018). In it together: Exploring how belonging to a youth activist group enhances well-being. Journal of Community Psychology, 46(1), 23-43. http://doi.org/10.1002/jcop.21914

Ryan, R., \& Deci, E. (2000). Self-determination theory and the facilitation of intrinsic motivation, social development, and well-being. The American Psychologist, 55(1), 68-78. https://doi.org/10.1037/0003-066X.55.1.68

Shamir, B. (1990). Calculations, Values, and Identities: The Sources of Collectivistic Work Motivation. Human Relations, 43(4), 313-332. https://doi.org/10.1177/001872679004300402

Shaw, C., Brady, L., \& Davey, C. (2011). Guidelines for research with children and young people. London, UK. https://doi.org/10.1111/jcpp.12457

Sheldon, K. M., \& Elliot, A. J. (1999). Goal striving, need satisfaction, and longitudinal well-being: The self-concordance model. Journal of Personality and Social Psychology, 76(3), 482-497. https://doi.org/10.1037/0022-3514.76.3.482

Sherrod, L. R. (2006). Promoting Citizenship and Activism in Today's Youth. In S. Ginwright, P. Noguera, \& J. Cammarota (Eds.), Beyond Resistance! Youth Activism and Community Change: New Democratic Possibilities for Practice and Policy for America's Youth (pp. 287-300). New York, London: Routledge. https://doi.org/10.4324/9780203961001

Sherrod, L. R. (2007). Civic engagement as an expression of positive youth development. In R. K. Silbereisen \& R. M. Lerner (Eds.), Approaches to positive youth development (pp. 59-74). London: SAGE.

Sullivan, L., Edwards, D., Johnson, N., \& McGillicuddy, K. (2003). An Emerging Model for Working with Youth: Community Organizing + Youth Development $=$ Youth Organizing. Occasional Papers Series on Youth Organizing, 1, 1-28.

Thoits, P. a, \& Hewitt, L. N. (2001). Volunteer work and well-being. Journal of Health and Social Behavior, 42, 115-131. https://doi.org/10.2307/3090173

Tugade, M. M., \& Fredrickson, B. L. (2004). Resilient Individuals Use Positive Emotions 
Cite as: Montague, A. C., \& Eiroa-Orosa, F. J. (2018). In it together: Exploring how belonging to a youth activist group enhances well-being. Journal of Community Psychology, 46(1), 23-43. http://doi.org/10.1002/jcop.21914

to Bounce Back From Negative Emotional Experiences. Journal of Personality and Social Psychology, 86(2), 320-333. https://doi.org/10.1037/0022-3514.86.2.320

Vestergren, S., Drury, J., \& Chiriac, E. H. (2016). The biographical consequences of protest and activism: a systematic review and a new typology. Social Movement Studies, 2837(November), 1-19. https://doi.org/10.1080/14742837.2016.1252665

Watkins, N. D., Larson, R. W., \& Sullivan, P. J. (2007). Bridging Intergroup Difference in a Community Youth Program. American Behavioral Scientist, 51(3), 380-402. https://doi.org/10.1177/0002764207306066

Watts, R. J., Diemer, M. A., \& Voight, A. M. (2011). Critical consciousness: Current status and future directions. New Directions for Child and Adolescent Development, 2011(134), 43-57. https://doi.org/10.1002/cd.310

Watts, R. J., \& Flanagan, C. (2007). Pushing the envelope on youth civic engagement: A developmental and liberation psychology perspective. Journal of Community Psychology, 35(6), 779-792. https://doi.org/10.1002/jcop.20178

Watts, R. J., Williams, N. C., \& Jagers, R. J. (2003). Sociopolitical development. American Journal of Community Psychology, 31(1-2), 185-194. https://doi.org/10.1023/A:1023091024140

Wilson, J. (2000). Volunteering. Annual Review of Sociology, 26(1), 215-240. https://doi.org/10.1146/annurev.soc.26.1.215

Wong, P. T. P. (2012). The human quest for meaning: Theories, research, and applications (2nd ed.) (Vol. 237). New York, NY: Routledge. https://doi.org/10.1080/14330237.2014.906179

Yohalem, N., \& Martin, S. (2007). Building the evidence base for youth engagement: Reflections on youth and democracy. Journal of Community Psychology, 35(6), 807-810. https://doi.org/10.1002/jcop.20180 
Cite as: Montague, A. C., \& Eiroa-Orosa, F. J. (2018). In it together: Exploring how belonging to a youth activist group enhances well-being. Journal of Community Psychology, 46(1), 23-43. http://doi.org/10.1002/jcop.21914

Youniss, J., Mclellan, J. a., \& Mazer, B. (2001). Voluntary Service, Peer Group Orientation, and Civic Engagement. Journal of Adolescent Research, 16(5), 456468. https://doi.org/10.1177/0743558401165003

Zimmerman, M. A., Stoddard, S. A., Eisman, A. B., Caldwell, C. H., Aiyer, S. M., \& Miller, A. (2013). Adolescent Resilience: Promotive Factors That Inform Prevention. Child Development Perspectives, 7(4), 215-220. https://doi.org/10.1111/cdep.12042 